\title{
Visitors' motivation and perception on Sangiran Early Man Museum, Krikilan Cluster
}

\section{Motivasi dan persepsi pengunjung terhadap Museum Manusia Purba Sangiran Klaster Krikilan}

\author{
Theresia L. Oktarisa, Anindia L. Prihatiningtias², Titi S. Prabawa², and \\ Linda Susilowati ${ }^{3}$ \\ University of Ferrara ${ }^{1}$, Universitas Kristen Satya Wacana², University of Sydney ${ }^{3}$ \\ mayszea5@gmail.com
}

\section{ABSTRAK}

Kata Kunci:

Motivasi

persepsi;

museum

Sangiran

destinasi

wisata

Keywords:

Motivation;

perception;

Sangiran

museum;

tourism

destination
Indonesia memiliki berbagai destinasi wisata yang termasuk dalam kategori Heritage Tourism, salah satunya adalah Situs Manusia Purba Sangiran. Pengelola Museum Manusia Purba Sangiran Klaster Krikilan dan empat museum lainnya harus mulai memperhatikan unsur-unsur penting dalam pengembangan dan pengelolaan destinasi pariwisata. Unsur-unsur penting meliputi atribut destinasi wisata yang dikaitkan dengan motivasi dan persepsi wisatawan mengenai seberapa besar kemampuan sebuah destinasi wisata memenuhi kebutuhan serta kepuasan wisatawan. Kepuasan wisatawan kemudian dijadikan sebagai salah satu indikator untuk menilai apakah sebuah destinasi wisata dapat dikategorikan sebagai destinasi unggulan. Artikel ini menyajikan hasil penelitian mengenai motivasi dan persepsi pengunjung atau wisatawan Klaster Krikilan Museum Manusia Purba yang dilakukan pada 533 responden menggunakan angket. Hasil penelitian disajikan secara deskriptif sehingga dapat memberikan kontribusi terhadap pemeliharaan, pengelolaan, dan pengembangan museum sebagai destinasi wisata unggulan.

\section{ABSTRACT}

One of Indonesia's tourist destinations which included in the Heritage Tourism category is Sangiran Early Man Site. As a tourist destination, The Sangiran Early Man Museum, Krikilan Cluster and four other museums, needs a concern to some important elements in the development and management of tourism destination. It comprises tourism destination attributes linked to the tourist motivation and perceptions towards necessities compliance, and tourist satisfaction of the destination. Tourist satisfaction became one of indicators whether the tourism destination can be considered as priority tourism destination. This article provides information on visitors' motivations and perceptions of Krikilan Cluster, the Sangiran Early Man Museum, based on quantitative research conducted on 533 responden. The descriptive results are expected to give contribution towards museum's maintenance, management, and development to be a primary tourist destination.

\begin{tabular}{|c|c|c|c|}
\hline 爱 1 & A & $\begin{array}{l}\text { VOLUME } \\
\text { DOI } \\
\text { VERSION } \\
\text { WEBSITE }\end{array}$ & $\begin{array}{l}: 41 \text { No.1, Mei 2021, 109-128 } \\
: \text { 10.30883/jba.v4li1.570 } \\
: \text { English (translated) } \\
: \text { berkalaarkeologi.kemdikbud.go.id }\end{array}$ \\
\hline ISSN: 0216-1419 & E-ISSN: 2548-7132 & (cc) (1)(9) & $\begin{array}{l}\text { This work is licensed under a Creative Commons Attribution-Non } \\
\text { Commercial-ShareAlike } 4.0 \text { International License }\end{array}$ \\
\hline
\end{tabular}




\section{INTRODUCTION}

Tourism industry is one of the fastest growing industries in Indonesia in recent years. Its multisector nature has made this industry attractive to various groups. Not only being a pillar of the country's economy, the tourism industry has also been considered as a forum in introducing the nation's natural wealth and cultural diversity. We can see one of the national cultural diversity through cultural and historical heritage tourist destinations or better known as Heritage Tourism.

Heritage Tourism is a tourism that utilizes heritage as a tourist attraction. Heritage tourism itself is oriented towards certain attractions, such as sociocultural, castle or kingdom, pilgrimage tourism, as well as archaeological and historical sites (Inskeep, 1991). The United Nations World Tourism Organization (UNWTO) noted that in 2005, tourist visits to cultural and historical heritage tourism objects or destinations became one of the tourist activities with the fastest growth rates. This is based on the existence of a new trend for tourists to seek something unique and authentic from a culture (Ardika, 2015). This growth has also occurred in various cultural and historical heritage tourist destinations in Indonesia. One of the destinations that later experienced development due to the growth of visitors is Sangiran Early Man Site.

Sangiran is geographically located between Sragen Regency and Karanganyar Regency, Central Java and has an area of $48 \mathrm{~km}^{2}$. In 1996, the United Nations of Educational, Scientific, and Cultural Organization (UNESCO) designated the Sangiran Site as a World Cultural Heritage called Sangiran Early Man Site. Sangiran later became an archaeological site that focuses on research purposes. Since 2005, Sangiran Site has been developed as a tourist destination with the construction of the Sangiran Early Man Museum. Office of Sangiran Early Man Site Preservation (BPSMP Sangiran) on its official website states that currently Sangiran Early Man Museum has 4 development clusters, namely, Krikilan Cluster, Dayu Cluster, Bukuran Cluster, and Manyarejo Cluster. Krikilan Cluster is a cluster that was first built and then developed into a visitor center by providing complete information about Sangiran Site. Therefore, Krikilan Cluster is the most frequently visited cluster.

The exhibition in Krikilan Cluster is divided into three spaces, namely, the Wealth of Sangiran room, the Steps of Humanity room, and the Golden Age of Homo erectus Golden Age diorama room. The first room is the Wealth of Sangiran Room which displays information about the finest fossil findings from Sangiran, human cultural products at the Sangiran Site, interesting dioramas and interactive props to support information for visitors. The second room is the Steps of Humanity which presents information about the early formation of the solar system according to the Big Bang Theory in the form of a short film, as well as the formation of the earth from its inception, to the settlement of the Nusantara archipelago. This information is packed in an animation form supported by a collection of fossils, artifacts, statues, and duplicate finds. The third room is the Golden Age of Homo erectus room which presents information about the description of Homo erectus life 500,000 years ago, both its environment and the life of the animals that existed at that time. Homo erectus historically was named as Pithecanthropus erectus. They lived in the Java Island between 1,8 to 0,15 million years ago. Homo erectus was discovered for the first time at Trinil, East Java by Eugene Dubois in 1891.

As a tourist destination, Sangiran Early Man Museum certainly needs to pay attention to important elements in the development and management of a 
tourist destination to be superior and sustainable. Referring to Cooper (Cooper et al., 2005), a tourist destination must fulfill the destination's attributes which include attraction, accessibility, amenities and ancillary facilities. Attraction can be defined as anything that are attractive and valuable to visit and see, while accessibility is something that helps tourists' access or reach tourist destinations easily. Next, amenities as facilities to support the needs of tourists when traveling, while ancillary service is defined as a service provider to tourists or a service provider to tourists. These attributes are often related to the motivation and perceptions of tourists about how much a tourist destination is capable of meeting the needs and satisfaction of tourists (Cooper et al., 2005).

Perception is defined as an individual process of giving meaning to the surrounding environment, both physical and social objects through sensing, integrating, and evaluating or interpreting activities (Gnanapala, 2015). This sensing depends on the physical stimuli and social stimuli in the environment. This then underlies different tourist behavior; this behavior can be either positive or negative behavior. According to Walgito, in processing the stimulus by the senses, organizational and interpretation processes occur which are influenced by factors of tourist characteristics, knowledge, expectations, and motives. It is not surprising that many studies on tourist perceptions have been carried out together or related to tourist motivation (Walgito, 2004).

In general, motivation is known as a thing or a factor that encourages someone to do something ( cited as a reason for tourists to visit tourist destinations that they will or want to visit, as well as a short process to see travel behavior (Anggela et al., 2017). Behavior is seen more in the direction of how motivation then affects a person's psychological needs and long-term plans. According to reviews by Cohen, placed intrinsic motives or motivation that arise on the basis of human consciousness itself (internal motivation such as self-actualization) as a very important component (Cohen, 1984). If Cohen focused on internal motivation, Trisnawati and Idaman found motivation to visit, especially in visiting museums, does not only involve internal motivation, but also external motivation (Trisnawati \& Idaman, 2019). Internal motivation can be exemplified such as motivation to increase knowledge, fulfill duties as a student, and create recreation to fulfill curiosity. The findings from Trisnawati and Idaman are also examples that can be said as external motivations, such as the factors of attractiveness and popularity of tourist destinations. However, the external factors put forward by Trisnawati and Idaman are still considered related to internal motivation.

Another study carried out by Jansen-Verbeke and Van Rekom argued that there are 24 motivations for tourists to visit a museum which are then classified into three main factors. The three main factors, namely, learning something, enriching life, and relaxation. The first factor "Learning Something" consists of nine motivations, namely, having a dynamic life, keep moving (not static), seeing things from a different point of view, telling others, positioning yourself as someone else, adding insight, profitable for work, learn something, find out about something, and learn something about the past. If the first factor consists of nine motivations, then the second factor "Enriching Life" consists of six motivations, namely, learning new things, seeing works of art, admiring other people's work, receiving benefits from experiences, looking back at something in the past, and visiting a museum. The third factor "Relaxation" consists of nine motivations, namely, being creative, enriching life, living a quality life, being active, selfsatisfaction, being in an open space, filling spare time, relaxing, and getting out 
of daily routines (Jansen-Verbeke \& Van Rekom, 1996).

The findings in qualitative research to know the motivation and behavior of tourists using the spatial tracking study method conducted by Rohman referring to the findings of motivation by Jansen-Verbeke and Van Rekom in Sangiran Early Man Museum, Krikilan Cluster. The results showed that the motivation to visit tourists had, among others, motivation to gain insight, motivation to learn something (especially the human past), motivation to find out about something, motivation to see something that has never been seen, motivation to look back on something from the past, motivation to relax or recreation, motivation in a spare time, and motivation to do side activities. Furthermore, motivation is related to the behavior of tourists who visit Sangiran Early Man Museum, Krikilan Cluster with the spatial tracking study method. The implications that arise are used to improve the presentation of the museum collection in order to fulfill the educational function, inspirational function, and recreational function of tourists (Rohman, 2014).

Previous research needs to be further developed to know specific motivations because museums are a form of tourism with special interests. Although the current research uses the same object as the previous research, namely tourists in Sangiran Early Man Museum, there are differences in the data to be studied, namely quantitative data. Rohman's research on visitor motivation was carried out in 2014, therefore if you look at the behavior of tourists that tends to be dynamic, these results do not necessarily represent the conditions of the Sangiran Early Man Museum tourists accurately and relevant. Given the changing behavior of tourists, research on tourist perceptions and motivations needs to be carried out periodically so that interested parties can continue to understand tourist behavior accurately. Research on tourist perceptions and motivation is often carried out simultaneously because these two things are considered to have an effect on tourist visits and the development of a tourism destination (Anggela et al., 2017; Pristiwasa, 2017; Sayangbatti \& Baiquni, 2013; N. B. P. Wibowo, 2012).

Recent research on the perception and motivation of tourist visits in Sangiran Early Man Museum needs to be done in order to obtain a reference for the development of the museum in accordance with the needs and desires of tourists. Through development in accordance with the needs, it is expected that there will be an increase in the satisfaction and interest of tourists to visit the tourist destination of Krikilan Cluster, Sangiran Early Man Museum. This is expected to have a positive impact on various other sectors around Sangiran Site. Based on this description, the objectives of this study can be formulated, 1) To know the demographics of tourists visiting Sangiran Early Man Museum, Krikilan Cluster 2) To know the things that motivate tourist visits to Krikilan Cluster, Sangiran Early Man Museum and 3) To know the perceptions on tourists in the attributes of tourist destination of Sangiran Early Man Museum, Krikilan Cluster.

\section{METHODS}

This descriptive quantitative research was conducted at Krikilan Cluster, Sangiran Early Man Museum from January 31 to February 29, 2020. Data was collected in a random choice of time from morning to evening, whether on weekdays, weekends, or holidays. Primary data from this study were obtained through a questionnaire distributed to tourists who independently filled out the questionnaire. The questionnaire contains 34 items of fixed-alternative questions 
measured using a Likert scale with 4 levels of agreement, 1) strongly disagree (STS), 2) disagree (TS), 3) agree (S), and 4) strongly agree (SS) on positive statements (favorable items). Secondary data includes literature review, references, and other data sources found by the authors related to this research.

The questionnaire distributed in the first part contains several questions regarding demographics such as, 1) Gender, 2) Visiting with Whom, 3) Occupation, 4) Current Residence, and 5) Recent Education. In the second part, the questionnaire presents questions about visitor motivation which are adapted from the questionnaire used in Rohman's 2015 research regarding the motivation of visitors to Krikilan Cluster, Sangiran Early Man Museum. The question item is derived from the three main factors that encourage tourists to visit the museum previously stated by Jansen-Verbeke and Van Rekom (Jansen-Verbeke \& Van Rekom, 1996).

The first category (motivation to "Learn Something") is derived into three statements, namely, 1) Gaining new knowledges into the environment, early humans, ancient objects, human history, old/ historic objects, and other things related to Sangiran Museum tourism destinations, 2) Obtaining stories about what we encountered during a visit to Sangiran Museum and its surroundings, and can share them with others, 3) Gaining experiences by positioning oneself as someone else. The second category ("Enriching Life" motivation) is derived into four statements, namely, 1) Appreciating or admiring the work of others, 2) Increasing creativity and obtaining benefits that can be used for what is being done, 3) Having a penchant for visiting various types of museums, 4) Enrich the meaning of life or improve the quality of life. The third category ("Relaxation" motivation) is then reduced to three statements, namely, 1) Recreation, relaxation, or taking a break from daily routines, 2) Eliminating boredom or making life more colorful and dynamic, 3) Getting a self-satisfaction.

In the third part of the questionnaire, there are questions about visitors' perceptions of the four attributes put forward by Cooper and his team (Cooper et al., 2005). The assessment on visitors' perceptions on the attribute of attraction is obtained from eight indicators related to whether the attribute of attractiveness are, 1) In accordance with tourist expectations, 2) Fulfilling tourist needs and motivation for recreation, 3) Educating or providing knowledge for tourists, 4) Fulfilling security and order standards of a tourist destination, 5) Meeting the standards of cleanliness of a tourist destination, 6) Meeting the standards of beauty of a tourist destination; 7) Meeting the coolness standards of a tourist destination, 8) Tourists want to visit again. The perception of visitors about accessibility (accessibilities) is seen from three indicators, namely, is the location, 1) Easy to find and has clear signposts, 2) Has good access and is easy to pass by motorized vehicles, 3) Has sufficient availability of public transportation. Perceptions of supporting facilities (Amenities) are assessed from the opinions of visitors to, 1) Availability of adequate and well-managed toilets, 2) The availability of adequate and well-managed parking lots, 3) Comfort of places of worship and well managed. Perceptions of the attributes of the Service Provider Institution (Ancillary) are seen from the opinions of visitors regarding whether, 1) Sangiran Early Man Museum employees are responsive in serving the needs of tourists, 2) Sangiran Early Man Museum employees are friendly and polite to tourists, 3) Quality of service in Sangiran Early Man Museum is good, 4) The money spent by tourists is commensurate with the service quality of Sangiran Early Man Museum. 
A total of 533 visitors to the Sangiran Early Man Museum were willing to participate in this research. The results obtained from all respondents were statistically processed and the results of the analysis were presented descriptively. The analysis is used in order to describe the collected data as it is without the intention of making generalized conclusions or generalizations (Muhson, 2006).

\section{RESEARCH RESULTS}

The collected data was processed and divided into several parts, namely, 1) participant demographic data, 2) motivation, and 3) perception. Based on the demographic data obtained, in general, it can be seen that the number of male and female respondents was quite balanced (59\% female and $41 \%$ male) with the majority age in the range of 17-25 (39\%). The next largest percentage of respondents was in the age range of under 17 years $(37 \%)$, then the age range of $26-45$ years $(17 \%)$. The smallest percentage of respondents was over 45 years of age $(7 \%)$.

Most of the respondents came from Central Java Province $(80 \%)$, while a small proportion came from outside Central Java (18\%), outside Java (1\%), and from outside Indonesia (1\%). The majority of respondents visited with friends $(78 \%)$ or with family $(21 \%)$. Only a small proportion of respondents visited alone $(1 \%)$.

The most recent educational background found in the respondents was high school (45\%), followed by junior high school education background (36\%). A small proportion of the respondents had an education background of Elementary School (11\%), Bachelor (5\%), Diploma (2\%) and the least was from a Postgraduate educational background (1\%). It was also found that the majority of museum visitors were students $(62 \%)$, while the rest were private employees (18\%), self-employed (16\%), ASN / TNI / Polri (civil servants) $(1 \%)$. There were also 18 respondents $(3 \%)$ who certified that their work did not fall into the stated category. Details of tourist characteristics data based on these demographics can be seen in Table 1.

Demographic data is useful to provide an overview on the characteristics of respondents who then express their motivations and perceptions of Sangiran Early Man Museum. This data can also be useful for future research on market segmentation for the development of tourist destinations. The results of data collection regarding visitor motivation with these characteristics are presented in three parts. The first section regarding "Learning Something" Motivation category can be seen in Table 2 .

From the Table 2 it can be seen that the majority of respondents strongly agree $(58 \%)$ and agree $(41 \%)$ that what motivated them was to add new insights. This means that almost all respondents (99\%) stated that they were motivated to add new insights about the environment, early humans, ancient objects, human history, old or historic objects, and other things related to the Sangiran Early Man Museum tourism destination. Most of the respondents also stated that what motivates them was the desire to gain experience by positioning themselves as someone else. This can be seen from the number of respondents who agree (85\%) and strongly agree (10\%) with the statement. Even so, there were a few who stated that the desire to gain experience by positioning themselves as other people was not what motivated them to visit Sangiran Early Man Museum. 
Table 1. Respondents characteristics based on demographics

\begin{tabular}{|c|c|c|c|c|}
\hline Indicator & Question & Total & Percentage & Total \\
\hline \multirow{2}{*}{ Sex } & Male & 221 & $41 \%$ & \multirow{2}{*}{$100 \%$} \\
\hline & Female & 312 & $59 \%$ & \\
\hline \multirow{4}{*}{ Age } & $<17$ yrs old & 196 & $37 \%$ & \multirow{4}{*}{$100 \%$} \\
\hline & $17-25$ yrs old & 209 & $39 \%$ & \\
\hline & $26-45$ yrs old & 91 & $17 \%$ & \\
\hline & $>45$ yrs old & 37 & $7 \%$ & \\
\hline \multirow{4}{*}{ Domicile } & Central Java & 427 & $80 \%$ & \multirow{4}{*}{$100 \%$} \\
\hline & Outside Central Java & 98 & $18 \%$ & \\
\hline & Outside Java & 5 & $1 \%$ & \\
\hline & $\begin{array}{l}\text { Outside Indonesia/ } \\
\text { Overseas }\end{array}$ & 3 & $1 \%$ & \\
\hline \multirow{3}{*}{ Came With } & Family & 111 & $21 \%$ & \multirow{3}{*}{$100 \%$} \\
\hline & Friend & 418 & $78 \%$ & \\
\hline & Alone & 4 & $1 \%$ & \\
\hline \multirow{6}{*}{ Latest Education } & Elementary & 56 & $11 \%$ & \multirow{6}{*}{$100 \%$} \\
\hline & Junior High & 191 & $36 \%$ & \\
\hline & Senior High & 241 & $45 \%$ & \\
\hline & Diploma & 13 & $2 \%$ & \\
\hline & Bachelor & 28 & $5 \%$ & \\
\hline & Posgraduate & 4 & $1 \%$ & \\
\hline \multirow{5}{*}{ Profession } & Student & 335 & $62 \%$ & \multirow{5}{*}{$100 \%$} \\
\hline & $\begin{array}{l}\text { Employees / Private } \\
\text { Emplovees }\end{array}$ & 94 & $18 \%$ & \\
\hline & Entrepreneur & 83 & $16 \%$ & \\
\hline & ASN/TNI/Polri & 3 & $1 \%$ & \\
\hline & Others & 18 & $3 \%$ & \\
\hline
\end{tabular}

Source: Theresia L. Oktarisa, Anindia L. Prihatiningtias, Titi S. Prabawa, Linda Susilowati

Table 2. Motivation "learning something"

\begin{tabular}{lllll}
\hline Description of Variable & $\begin{array}{l}\text { Level of } \\
\text { Agreement }\end{array}$ & Total & Percentage & Total \\
\hline Gaining new knowledges about the & Agree & 222 & $41 \%$ & \\
environment, ancient humans, ancient objects, & Strongly agree & 310 & $58 \%$ & \multirow{2}{*}{$100 \%$} \\
human history, old / historic objects, and other & Disagree & 1 & $1 \%$ & \\
things related to Sangiran Museum tourism & Strongly Disagree & 0 & $0 \%$ & \\
destinations. & Agree & 455 & $85 \%$ & \\
To gain experience by positioning yourself as & Strongly agree & 55 & $10 \%$ & \\
someone else & Disagree & 22 & $4 \%$ & \\
& Strongly Disagree & 1 & $1 \%$ & $100 \%$ \\
To obtain stories about what we encountered & Agree & 404 & $76 \%$ & \\
during a visit to Sangiran Museum and its & Strongly agree & 110 & $20 \%$ & \\
surroundings, and able to share them with & Disagree & 18 & $3 \%$ & \\
others & Strongly Disagree & 1 & $1 \%$ & \\
\hline
\end{tabular}

Source: Theresia L. Oktarisa, Anindia L. Prihatiningtias, Titi S. Prabawa, Linda Susilowati

Besides gaining new knowledge and experience, most of the respondents were also motivated to obtain stories about what they encountered during their visit to Sangiran Museum and its surroundings when deciding on a trip. This can be seen from the majority of respondents who agree $(76 \%)$ and strongly agree $(20 \%)$ with the statement. However, there were also respondents who did not think that this was something that motivated them to visit the museum by disagree $(3 \%)$ and strongly disagree $(1 \%)$ with the statement.

The second part on the results of data processing regarding visitor motivation which is categorized as "Enriching Life" Motivation category can be seen in Table 3 . Through these data in Table 3 , it is shown that most of the research respondents were motivated to enrich the meaning of life or improve the quality 
of life when they decided to visit the Sangiran Early Man Museum. This can be seen from the $79 \%$ of respondents who agreed and $18 \%$ who strongly agreed with the statement, while the rest said they disagreed (3\%), which means they do not feel that it encourages them to visit the museum. Most of the respondents also stated that one of the respondents' motivations when visiting Sangiran Early Man Museum was to appreciate or admire other people's work by agreeing $(84 \%)$ and strongly agreeing $(12 \%)$ on the statement regarding this matter. Only a small proportion of respondents thought this was not their motivation (3\% disagreed and $1 \%$ strongly disagreed).

Table 3. Motivation of "enriching life"

\begin{tabular}{|c|c|c|c|c|}
\hline Variable Description & Level of Agreement & Total & Percentage & Total \\
\hline \multirow{4}{*}{$\begin{array}{l}\text { Enrich the meaning of life or } \\
\text { improve the quality of life. }\end{array}$} & Agree & 421 & $79 \%$ & \multirow{4}{*}{$100 \%$} \\
\hline & Strongly agree & 95 & $18 \%$ & \\
\hline & Disagree & 17 & $3 \%$ & \\
\hline & Strongly Disagree & 0 & $0 \%$ & \\
\hline \multirow{4}{*}{$\begin{array}{l}\text { To appreciate or admire the work } \\
\text { of others }\end{array}$} & Agree & 450 & $84 \%$ & \multirow{4}{*}{$100 \%$} \\
\hline & Strongly agree & 66 & $12 \%$ & \\
\hline & Disagree & 16 & $3 \%$ & \\
\hline & Strongly Disagree & 1 & $1 \%$ & \\
\hline \multirow{4}{*}{$\begin{array}{l}\text { Have a penchant for visiting } \\
\text { various types of museums. }\end{array}$} & Agree & 436 & $81 \%$ & \multirow{4}{*}{$100 \%$} \\
\hline & Strongly agree & 72 & $14 \%$ & \\
\hline & Disagree & 25 & $5 \%$ & \\
\hline & Strongly Disagree & 0 & $0 \%$ & \\
\hline \multirow{4}{*}{$\begin{array}{l}\text { To increase creativity and obtain } \\
\text { benefits that can be used for } \\
\text { what is being done. }\end{array}$} & Agree & 444 & $83 \%$ & \multirow{4}{*}{$100 \%$} \\
\hline & Strongly agree & 65 & $12 \%$ & \\
\hline & Disagree & 24 & $5 \%$ & \\
\hline & Strongly Disagree & 0 & $0 \%$ & \\
\hline
\end{tabular}

Source: Theresia L. Oktarisa, Anindia L. Prihatiningtias, Titi S. Prabawa, Linda Susilowati

Through these data, it is shown that most of the research respondents were motivated to enrich the meaning of life or improve the quality of life when they decided to visit the Sangiran Early Man Museum. This can be seen from the 79\% of respondents who agreed and $18 \%$ who strongly agreed with the statement, while the rest said they disagreed $(3 \%)$, which means they do not feel that it encourages them to visit the museum. Most of the respondents also stated that one of the respondents' motivations when visiting Sangiran Early Man Museum was to appreciate or admire other people's work by agreeing (84\%) and strongly agreeing $(12 \%)$ on the statement regarding this matter. Only a small proportion of respondents thought this was not their motivation (3\% disagreed and 1\% strongly disagreed).

The data also showed that the majority of respondents stated that they were motivated to increase creativity and obtain benefits that can be used for what they are doing, when visiting the Sangiran Early Man Museum. This was indicated by $83 \%$ of respondents who agree and $12 \%$ who strongly agree with the statement, while only 5\% disagree. Even so, most of the respondents also stated that, one of their motivations for visiting Sangiran Early Man Museum was because they basically had a hobby of visiting various museums (81\% agree and $14 \%$ strongly agree). There was only a small number of respondents who thought that this was not what motivated them by expressing their disagreement (5\%).

The third part of the results of data processing regarding visitor motivation which is categorized in the "Relaxation" Motivation category can be seen in Table 4. It is shown in the data that most of the respondents stated that one of their motivations for visitation was to get rid of boredom, or to make life more colorful 
and dynamic (82\% agree and $14 \%$ strongly agree). Even so, there was a small number of respondents who did not think that this is what motivated them to visit, by disagreeing (2\%) and strongly disagreeing (1\%) on the statement. Most of the respondents also stated that, one of their motivations for visiting Sangiran Museum were for recreation, relaxation, or taking a break from daily routines (78\% agree and $20 \%$ strongly agree). Only 8 respondents $(2 \%)$ did not think that this was their motivation for visiting the museum. Besides that, most of the respondents also stated that they visited Sangiran Museum to fulfill their own satisfaction. This was indicated by the number who agreed (78\%) and strongly agreed (9\%) with this statement. However, a small number of respondents felt that they did not visit Sangiran Early Man Museum to fulfill their own satisfaction (12\% disagreed and 1\% strongly disagreed). Based on the description of these data, it can be seen that there were at least 10 things that can be considered as motivation for the majority of visitors in visiting Sangiran Early Man Museum, Krikilan Cluster.

Table 4. Motivation "relaxation"

\begin{tabular}{lllll}
\hline Variable Description & Level of Agreement & Total & Percentage & Total \\
\hline Eliminating boredom or to make & Agree & 439 & $82 \%$ & \\
life more colorful and dynamic. & Strongly agree & 80 & $14 \%$ & \multirow{2}{*}{$100 \%$} \\
& Disagree & 13 & $2 \%$ & \\
& Strongly Disagree & 1 & $1 \%$ & \\
For recreation, relaxation, or a & Agree & 417 & $78 \%$ & \multirow{2}{*}{$100 \%$} \\
break from daily routine & Strongly agree & 108 & $20 \%$ & \\
& Disagree & 8 & $2 \%$ & \\
& Strongly Disagree & 0 & $0 \%$ & \multirow{2}{*}{$100 \%$} \\
\hline \multirow{2}{*}{ To get self-satisfaction } & Agree & 422 & $78 \%$ & \\
& Strongly agree & 47 & $9 \%$ & \\
\hline
\end{tabular}

Source: Theresia L. Oktarisa, Anindia L. Prihatiningtias, Titi S. Prabawa, Linda Susilowati

The next result showed the perception of visitors on Sangiran Early Man Museum, Krikilan cluster based on the four leading tourism attributes as formulated by Cooper and his team (Cooper et al., 2005). Therefore, the data can be presented in four parts. The first part regarding attraction or attractiveness can be seen in Table 5 .

Table 5. Perceptions of museum attraction

\begin{tabular}{|c|c|c|c|c|c|c|}
\hline \multirow{2}{*}{ No } & \multirow{2}{*}{ Assessment Indicator } & \multicolumn{4}{|c|}{ Perception } & \multirow{2}{*}{ Total } \\
\hline & & SS & $\mathbf{s}$ & TS & STS & \\
\hline 1 & $\begin{array}{l}\text { In accordance with tourist } \\
\text { expectations }\end{array}$ & $\begin{array}{l}103 \\
(19 \%)\end{array}$ & $\begin{array}{l}420 \\
(79 \%)\end{array}$ & $\begin{array}{l}10 \\
(2 \%)\end{array}$ & $\begin{array}{l}0 \\
(0 \%)\end{array}$ & $\begin{array}{l}533 \\
(100 \%)\end{array}$ \\
\hline 2 & $\begin{array}{l}\text { Fulfilling the needs and motivation } \\
\text { for tourist recreation }\end{array}$ & $\begin{array}{l}95 \\
(18 \%)\end{array}$ & $\begin{array}{l}433 \\
(81 \%)\end{array}$ & $\begin{array}{l}5 \\
(1 \%)\end{array}$ & $\begin{array}{l}0 \\
(0 \%)\end{array}$ & $\begin{array}{l}533 \\
(100 \%)\end{array}$ \\
\hline 3 & $\begin{array}{l}\text { Educate or provide knowledge for } \\
\text { tourists }\end{array}$ & $\begin{array}{l}247 \\
(46 \%)\end{array}$ & $\begin{array}{l}257 \\
(50 \%)\end{array}$ & $\begin{array}{l}19 \\
(4 \%)\end{array}$ & $\begin{array}{l}0 \\
(0 \%)\end{array}$ & $\begin{array}{l}533 \\
(100 \%)\end{array}$ \\
\hline 4 & $\begin{array}{l}\text { Meet the security and order } \\
\text { standards of a tourist destination }\end{array}$ & $\begin{array}{l}56 \\
(11 \%)\end{array}$ & $\begin{array}{l}414 \\
(76 \%)\end{array}$ & $\begin{array}{l}62 \\
(12 \%)\end{array}$ & $\begin{array}{l}1 \\
(1 \%)\end{array}$ & $\begin{array}{l}533 \\
(100 \%)\end{array}$ \\
\hline 5 & $\begin{array}{l}\text { Meet the cleanliness standards of a } \\
\text { tourist destination }\end{array}$ & $\begin{array}{l}71 \\
(13 \%)\end{array}$ & $\begin{array}{l}309 \\
(58 \%)\end{array}$ & $\begin{array}{l}147 \\
(28 \%)\end{array}$ & $\begin{array}{l}6 \\
(1 \%)\end{array}$ & $\begin{array}{l}533 \\
(100 \%)\end{array}$ \\
\hline 6 & $\begin{array}{l}\text { Meet the beauty standards of a } \\
\text { tourist destination }\end{array}$ & $\begin{array}{l}84 \\
(16 \%)\end{array}$ & $\begin{array}{l}369 \\
(69 \%)\end{array}$ & $\begin{array}{l}78 \\
(14 \%)\end{array}$ & $\begin{array}{l}2 \\
(1 \%)\end{array}$ & $\begin{array}{l}533 \\
(100 \%)\end{array}$ \\
\hline 7 & $\begin{array}{l}\text { Meet the coolness standards of a } \\
\text { tourist destination }\end{array}$ & $\begin{array}{l}90 \\
(17 \%)\end{array}$ & $\begin{array}{l}412 \\
(77 \%)\end{array}$ & $\begin{array}{l}31 \\
(6 \%)\end{array}$ & $\begin{array}{l}0 \\
(0 \%)\end{array}$ & $\begin{array}{l}533 \\
(100 \%)\end{array}$ \\
\hline 8 & Tourists want to visit again & $\begin{array}{l}67 \\
(13 \%)\end{array}$ & $\begin{array}{l}456 \\
(85 \%)\end{array}$ & $\begin{array}{l}10 \\
(2 \%)\end{array}$ & $\begin{array}{l}0 \\
(0 \%)\end{array}$ & $\begin{array}{l}533 \\
(100 \%)\end{array}$ \\
\hline
\end{tabular}

Source: Theresia L. Oktarisa, Anindia L. Prihatiningtias, Titi S. Prabawa, Linda Susilowati 
This data shows that most of the respondents thought that the attractiveness of Sangiran Early Man Museum was in accordance with what was expected (79\% agree and $19 \%$ strongly agree). There was only $2 \%$ of respondents who did not think that the attraction of the museum was as expected by giving a statement of disagreement. Most of the respondents also thought that the attractiveness of the Sangiran Museum had fulfilled the recreational needs and motivation of tourists with many respondents who strongly agreed (18\%) and agreed $(81 \%)$ to the related statement, while only a few respondents expressed disagreement $(1 \%)$ against the statement. The majority of respondents also thought that the Sangiran Early Man Museum already had an attraction in educating or providing knowledge to tourists. This can be seen from the presence of $46 \%$ of respondents who agreed and $50 \%$ of respondents who strongly agreed with this statement, even though there were still $4 \%$ of respondents who disagreed.

Other indicators refer to 6 of the 7 aspects of Sapta Pesona, namely, security and order, cleanliness, beauty, coolness, and memories. The Sapta Pesona aspect that was not found in the attractiveness attribute, namely the warm-hearted aspect, can be seen in the ancillary attribute. Regarding the attraction of the museum which refers to the Sapta Pesona aspect, the data shows that the majority of respondents are of the opinion that the Sangiran Early Man Museum has met the safety and order standards for a destination (76\% agree and 11\% strongly agree). However, there were still respondents who argue that the Sangiran Early Man Museum has not met the standards of safety and order for a destination by not agreeing with the related statement (12\% disagree and $1 \%$ strongly disagree). In the aspect of cleanliness, there are a number of respondents who think that the museum has met the cleanliness standards of a good destination (13\% strongly agree and $58 \%$ agree). Although, there were also respondents who disagreed $(28 \%)$ and strongly disagreed $(1 \%)$ on the related statements. This means that there are 154 people from 533 respondents who think that the cleanliness at Sangiran Museum has not met the cleanliness standards of a tourism destination.

The data displayed shows that most of the respondents thought that Sangiran Early Man Museum has met the aesthetic standards for a tourist destination (15\% strongly agree and 69\% agree), although there were still some respondents who did not think so (15\% disagree and 1\% strongly not). Most of the respondents also thought that the Sangiran Early Man Museum had met the coolness standard for a tourist destination by strongly agreeing $(17 \%)$ and agreeing $(77 \%)$ to the related statement. There were only a small number of respondents who still thought that Sangiran Early Man Museum has not met the temperature standard by disagreeing $(6 \%)$.

The results showed that although there were a number of respondents who argued that the Sangiran Early Man Museum has not met the Sapta Pesona of a tourism destination, most of the respondents said they wanted to make a return visit to the Sangiran Early Man Museum. These results can be seen from the majority of visitors who agree $(85 \%)$ and strongly agree $(13 \%)$ with this statement, although there were still a small number of respondents who did not want to return to visit by stating that they disagree $(2 \%)$ on the statement.

The second part on the results of data processing regarding visitor perceptions is the perception of accessibility, namely location and road directions, access for motorized vehicles, and availability of public transportation. Data regarding respondents' perceptions of accessibility can be seen in Table 6 . 
Table 6. Perceptions of accessibility

\begin{tabular}{lllllll}
\hline \multirow{2}{*}{ No } & \multirow{2}{*}{ Assessment Indicator } & \multicolumn{3}{c}{ Perception } & \multicolumn{2}{c}{ Total } \\
& & SA & A & D & SD & \\
\hline \multirow{2}{*}{1} & The location is easy to find and has & 61 & 376 & 93 & 3 & 533 \\
& clear signposts & $(11 \%)$ & $(71 \%)$ & $(17 \%)$ & $(1 \%)$ & $(100 \%)$ \\
\multirow{2}{*}{2} & Has good access and is easily & 69 & 376 & 75 & 13 & 533 \\
& accessible by motorized vehicles & $(13 \%)$ & $(71 \%)$ & $(14 \%)$ & $(2 \%)$ & $(100 \%)$ \\
3 & The availability of public & 53 & 279 & 148 & 53 & 533 \\
& transportation is sufficient & $(10 \%)$ & $(52 \%)$ & $(28 \%)$ & $(10 \%)$ & $(100 \%)$ \\
\hline
\end{tabular}

Source: Theresia L. Oktarisa, Anindia L. Prihatiningtias, Titi S. Prabawa, Linda Susilowati

Notes:

SA: Strongly Agree

A: Agree

D: Disagree

SD: Strongly Disagree

The data in Table 6 shows that the majority of respondents are of the opinion that the location of the Sangiran Early Man Museum was easy to find and there was a fairly good availability of signposts to the location. This can be seen from the majority of respondents who agree (71\%) and strongly agree $(11 \%)$ with the related statements. However, there were still a number of respondents who thought that the location of the Sangiran Early Man Museum is not easy to find and the availability of signposts to the location is also not good (17\% disagree and $1 \%$ strongly disagree). Regarding the good quality of access and easy access for motorized vehicles, most of the respondents thought this had been fulfilled by agreeing $(71 \%)$ and strongly agreeing $(13 \%)$ to the statement. However, there are still a number of respondents who argued that the quality and ease of access to the Sangiran Early Man Museum has not been fulfilled (14\% disagree and 2\% strongly disagree)

The last indicator is the participant's perception of the availability of public transportation to Sangiran Early Man Museum. Table 6 shows the data that the majority of respondents think that the availability of public transportation to Sangiran Early Man Museum is sufficient, most of them agree (52\%) and strongly agree $(10 \%)$ with this statement. However, there was $28 \%$ of respondents who disagreed and $10 \%$ who strongly disagreed with the statement regarding the availability of public transportation at Sangiran Early Man Museum. Referring to this data, it means that there are 201 people out of 533 respondents who think that the availability of public transportation is not sufficient. Therefore, the issue regarding the availability of public transportation to Sangiran Early Man Museum needs special attention.

The third part regarding perception was the participant's perception of the existing supporting facilities in Sangiran Early Man Museum. Supporting facilities have an important role for a tourist destination, in supporting the comfort of visitors during their tour. Data regarding visitors' perceptions of the supporting facilities of the Sangiran Early Man Museum can be seen in Table 7.

Table 7. Perception on supporting facilities

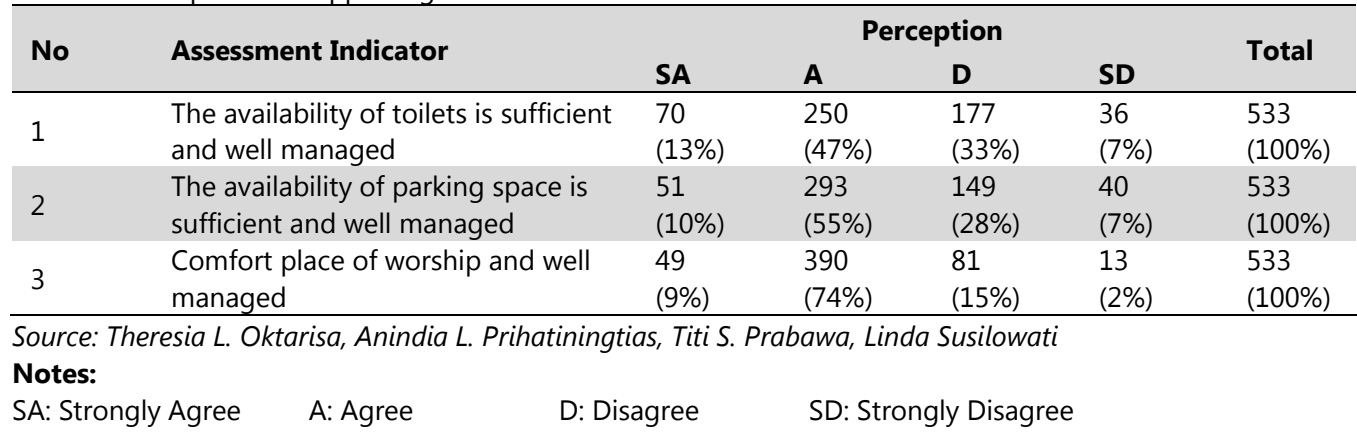


Table 7 presents data which shows that although the majority of respondents thought that the supporting facilities for the Sangiran Early Man Museum in the form of toilets are available and well managed $(47 \%$ agree and $13 \%$ strongly agree), there is $33 \%$ of respondents who disagree and $7 \%$ respondents who strongly disagree with the statement. This means that 213 out of 533 respondents do not consider that Sangiran Early Man Museum to have sufficient toilet availability and proper toilet management. Similar conditions were also found related to respondents' perceptions of the availability of parking space and management in museums. Although most of the respondents thought that the availability of parking space is sufficient and its management is carried out well (55\% agree and $10 \%$ strongly agree), there are respondents who disagree $(28 \%)$ and respondents who strongly disagree $(7 \%)$. This means that there are 189 people who think that the availability of parking space at the Sangiran Early Man Museum is not sufficient and its management has not been carried out properly.

The perception of visitors to other supporting facilities that are also seen in this study is the perception of visitors to the comfort of places of worship and their management. It can be seen that most of the respondents think that the places of worship available in the Sangiran Early Man Museum are comfortable and well managed (74\% agree and $9 \%$ strongly agree). There is only $15 \%$ of respondents who disagree and $2 \%$ of respondents strongly disagree with this statement.

The fourth part of the data regarding the visitor's perception of the tourism attributes in Sangiran Early Man Museum is the visitor's perception on the services and services provided to tourists. When referring to the Sapta Pesona aspects, the visitor's perception of these services is included in the suave aspect. The results obtained from the responses of research respondents can be seen in Table 8.

Table 8. Perceptions on service providers

\begin{tabular}{|c|c|c|c|c|c|c|}
\hline \multirow{2}{*}{ No } & \multirow{2}{*}{ Assessment Indicator } & \multirow[b]{2}{*}{ SA } & \multicolumn{2}{|c|}{ Perception } & \multirow[b]{2}{*}{ SD } & \multirow[t]{2}{*}{ Total } \\
\hline & & & A & D & & \\
\hline 1 & $\begin{array}{l}\text { Sangiran Ancient Man Museum employees } \\
\text { are responsive in serving the needs of } \\
\text { tourists }\end{array}$ & $\begin{array}{l}88 \\
(17 \%)\end{array}$ & $\begin{array}{l}423 \\
(79 \%)\end{array}$ & $\begin{array}{l}22 \\
(4 \%)\end{array}$ & $\begin{array}{l}0 \\
(0 \%)\end{array}$ & $\begin{array}{l}533 \\
(100 \%)\end{array}$ \\
\hline 2 & $\begin{array}{l}\text { Sangiran Ancient Man Museum employees } \\
\text { are friendly and courteous to tourists }\end{array}$ & $\begin{array}{l}110 \\
(21 \%)\end{array}$ & $\begin{array}{l}399 \\
(75 \%)\end{array}$ & $\begin{array}{l}22 \\
(4 \%)\end{array}$ & $\begin{array}{l}2 \\
(0 \%)\end{array}$ & $\begin{array}{l}533 \\
(100 \%)\end{array}$ \\
\hline 3 & $\begin{array}{l}\text { The service quality at Sangiran Ancient } \\
\text { Man Museum is already good }\end{array}$ & $\begin{array}{l}75 \\
(14 \%)\end{array}$ & $\begin{array}{l}443 \\
(83 \%)\end{array}$ & $\begin{array}{l}15 \\
(3 \%)\end{array}$ & $\begin{array}{l}0 \\
(0 \%)\end{array}$ & $\begin{array}{l}533 \\
(100 \%)\end{array}$ \\
\hline 4 & $\begin{array}{l}\text { The money spent by tourists is } \\
\text { commensurate with the service quality of } \\
\text { Sangiran Ancient Man Museum }\end{array}$ & $\begin{array}{l}54 \\
(10 \%)\end{array}$ & $\begin{array}{l}471 \\
(88 \%)\end{array}$ & $\begin{array}{l}8 \\
(2 \%)\end{array}$ & $\begin{array}{l}0 \\
(0 \%)\end{array}$ & $\begin{array}{l}533 \\
(100 \%)\end{array}$ \\
\hline
\end{tabular}

Source: Theresia L. Oktarisa, Anindia L. Prihatiningtias, Titi S. Prabawa, Linda Susilowati Notes:

SA: Strongly Agree A: Agree $\quad$ D: Disagree SD: Strongly Disagree

It can be seen in Table 8 which shows that most tourists think that the employees of Sangiran Early Man Museum are quite responsive in serving the needs of tourists (79\% agree and $17 \%$ strongly agree) and there is only $4 \%$ who disagree with the statement. With regard to service, as well as perceived service responsiveness, the majority of respondents also thought that the service of Sangiran Early Man Museum employees is friendly and has good manners (75\% agreed and $21 \%$ strongly agreed). Respondents who did not have this opinion are very small, with $4 \%$ who disagree and $1 \%$ who strongly disagree with the statement. 
Most of the respondents also saw that the service quality of the Sangiran Early Man Museum already met the standards of a good tourist destination. This can be seen from the majority of respondents who agree $(83 \%)$ and stated that they strongly agree with the statement $(14 \%)$, while the rest who disagree with the statement only amounted to 3\%. The latest data shown in Table 8 shows that the majority of respondents think that the money or costs incurred by visitors are in accordance with the quality of service received with $88 \%$ of respondents who agreed and $10 \%$ of respondents who expressed their utmost agreement with the statement. Thus, only $2 \%$ thought that the money spent by visitors was not in accordance with the quality of service received.

\section{DISCUSSIONS}

Through the explanation of the research results it can be seen that, although the majority of visitors or tourists who were respondents in this study were women, the difference in numbers was not too big. The difference in demographic data that was quite striking was the origin of tourists, $80 \%$ of which came from Central Java, $62 \%$ who were students, and 78\% visited with friends. This means that most tourists at Krikilan Cluster, Sangiran Early Man Museum are students from Central Java who visited with friends. In this regard, if we refer to the data collection time which was mostly done on working days and hours, it can be analyzed that the visits made by the majority of visitors were mostly activities organized by educational institutions. Various studies in Indonesia regarding museum visitors have also found similar things, the majority of museum visitors are students who are taking study tours or carrying out assignments from school (Fitriana et al., 2020; Gaffar, 2011; A. J. I. Wibowo, 2015) . Thus, it can be said that the visit made by the majority of visitors to Sangiran Early Man Museum cannot be ascertained because of the personal impulse of tourists or because of the special interest of tourists towards certain themes such as prehistoric life, culture and science.

The data shows, although the encouragement from the majority of respondents is not yet certain whether it comes from themselves, this study found ten things that can be considered as the main motivation of tourists when visiting Krikilan Cluster, Sangiran Early Man Museum. This motivation can be divided into three categories according to the categorization stated by Jansen-Verbeke and Van Rekom that is, learning something, enriching life, and relaxing. Among the ten main motivations, the least that was found in the respondents was motivation to gain self-satisfaction which is included in the "relaxation" category, while the motivation most often found among tourists was the desire to gain insight (Jansen-Verbeke \& Van Rekom, 1996). The insights referred to in the statement are new knowledges regarding the environment, early humans, ancient objects, human history, old and historic objects, and other things related to the attraction of Krikilan Cluster, Sangiran Early Man Museum tourist destinations. Referring to what Jansen-Verbeke and Van Rekom said, the desire to add insight can be categorized as an encouragement to "learn something".

Jansen-Verbeke and Van Rekom in their writings explains that the motivation to "learn something" is a central motivation or motivation that has a strong relationship with other motivations. In the context of visiting a museum, central motivation is considered the main theme, while other motivations are divided into groups around them. An example of motivation for "learning something" can be achieved by seeing or admiring the work of others in museums. The activity of seeing and admiring other people's work in order to 
learn something can also fall into another motivation category, namely motivation to enrich life. Therefore, it is not surprising that in various studies on the motivation of museum visitors, this motivation is mostly found in respondents. Thus, it can be seen that the motivation for the visit most often found in visitors to the Sangiran Early Man Museum is similar to the main motivation found in museum visitors in general.

The large number of visitors who have the motivation to learn something when visiting the museum is inseparable from one of the functions and attractions of the museum itself, especially in presenting a variety of knowledge. Attractiveness is an important attribute in supporting a tourist destination to become superior (Cooper et al., 2005). Therefore, existing tourist destinations need to have their own appeal for tourists, including if then the destination is a museum.

Despite its attractiveness, the perception of the attractiveness of each museum is not always the same for tourists who come to visit. Sangiran Early Man Museum can be said to have met the standard of attractiveness attributes for a tourist destination. This of course refers to the statement of the majority of respondents with the perception that Sangiran Early Man Museum already has dishes that can attract tourists to visit. In addition, the majority of research respondents stated that the attractiveness of the Sangiran Early Man Museum is in line with their expectations.

In addition to having an appeal considered to be in accordance with the expectations of the respondents, the services provided by employees were also considered to have met the standards of leading tourist destinations. Research respondents thought that Sangiran Early Man Museum has served quality services, responsive, friendly, and polite. In addition, respondents thought that the fees incurred were in accordance with the quality of services provided. Based on the perceptions of visitors, it can be interpreted that the quality of Sangiran Museum's employee services and ancillary service can be said to be good. The visitor's perception of such a good Ancillary attribute certainly affects the marketing of the Sangiran Early Man Museum as a tourist destination. This is in accordance with the reviews by Sugiama who describes ancillary services to facilitate and encourage the development and marketing of tourism from a tourist destination (Sugiama, 2011).

The results showed that overall, the majority of respondents think that the attributes in Krikilan Cluster was sufficient to meet the size of the leading tourism destinations, although there were things that need special attention. One of them was regarding supporting facilities (Amenities) such as the cleanliness aspect of the museum. The cleanliness of the museum needed special attention because there was a fairly large percentage of respondents who thought that the cleanliness of Sangiran Early Man Museum still did not meet the hygiene standards of visitors. The same opinion was also found regarding other supporting facilities in the museum, one of which was the toilet. This can be seen from the $40 \%$ of respondents who thought that the availability of toilets in Sangiran Early Man Museum was not sufficient and has not been properly managed. Regarding the availability of parking space which $35 \%$ of respondents considered insufficient and well managed. Apart from that, regarding the comfort and management of places of worship, $17 \%$ of the respondents also thought these facilities had not been carried out properly.

Another part that deserved special attention was the visitor's perception of accessibility). According to Suwantoro good accessibility will determine the ease 
of location for visitors to reach. In addition, Suswantoro added that road access also affects the smooth running of public services (Suwantoro, 1997). Although in terms of the percentage of respondents who think that the accessibility in the Krikilan Cluster, Sangiran Early Man Museum has met the standards, there are a number of respondents who have an opinion that the Krikilan Cluster, Sangiran Early Man Museum does not have good access. As much as $38 \%$ of all respondents thought that the availability of public transportation to the museum had not been fulfilled properly, as well as the directions to the museum location which $18 \%$ of respondents considered had not been properly fulfilled by the manager. In addition to access to public transportation and directions, easy access for motorized vehicles was considered by $16 \%$ of respondents not to be properly fulfilled.

The percentage of results above is related to the understanding of motivation and perceptions possessed by visitors to Krikilan Cluster, Sangiran Early Man Museum, of course can provide an overview for the parties concerned. This description, among others, is to be able to map things that need to be maintained or maintained, as well as map the parts that need to be developed or improved.

\section{CONCLUSION}

Based on the data that has been described, it can be concluded that the profile of tourists who mostly visit Krikilan Cluster, Sangiran Early Man Museum is partly students from Central Java who visit with friends. Most of the visits are carried out in the context of participating in activities organized by the school or educational institution. The motivation of these tourists on average is to learn something, "enrich" their life, and relax or seek entertainment. Among these things, the motivation most often found in tourists is to add new insights into the early human environment, ancient objects, human history, old and historic objects, and other things related to the attractiveness of Krikilan Cluster, Sangiran Early Man Museum tourist destinations.

Almost all tourists involved in the study agreed that the attraction of Krikilan Cluster, Sangiran Early Man Museum is in accordance with the expectations, needs, and motivations of the respondents for recreation. In addition, the majority of tourists think that Krikilan Cluster, Sangiran Early Man Museum has provided services that are responsive, friendly, courteous, and considered quality. However, there are still a number of tourists who think Krikilan Cluster, Sangiran Early Man Museum still does not meet the cleanliness standards for a destination. For examples is the supporting facilities available, namely toilets. Apart from toilets, other supporting facilities such as parking lots and places of worship are also considered by a number of tourists not to meet the needs of visitors. Likewise, the accessibility that some tourists consider has not fulfilled the needs of visitors. Signposts, access to the location, and the availability of public transportation to Krikilan Cluster, Sangiran Early Man Museum are still considered unable to meet the needs of visitors.

\section{RECOMMENDATIONS}

Based on this research, the researcher referred to the parties related to the management of Sangiran Early Man Museum and the surrounding environment to maintain the things that considered by the respondents as good and motivating. For example, such as the attraction of a tourist destination which is related not only to the ability to educate and provide insight, but also other things 
such as beauty and coolness. The researcher also provides a reference so that Krikilan Cluster, Sangiran Early Man Museum can improve supporting facilities such as toilets, parking lots, and places of worship. Also looking for a solution for some of the respondents who think about the insufficient access to public transportation, directions, and easy access to Sangiran Early Man Museum by motor vehicles.

The researcher also provides references for related parties to carry out further research that can assist in the preparation of programs for the maintenance, management and development of Sangiran Early Man Museum, both from the perspective of tourists and other parties such as the community around the museum. In this regard, subsequent research will further enrich knowledge if it is able to map the motivation, perception, and satisfaction of visitors in different demographics.

\section{AUTHOR DECLARATION}

All Authors contributed to the creation of this manuscript. First author (Theresia Lukita Oktarisa) and second author (Anindia Larasati Prihatiningtias) served as primary contributors, while third author (Titi Susilowati Prabawa) and fourth author (Linda Susilowati) served as secondary contributors. The manuscript has been read and approved by all authors. The order of authors listed in the manuscript has been approved by all named authors. All authors received funding for the creation of this manuscript from Internal Research Funding of UKSW. All authors confirm that there are no known conflicts of interest associated with this publication and there has been no significant financial support for this work that could have influenced its outcome. All authors adhered to the Copyright Notice set by Berkala Arkeologi. 


\section{REFERENCES}

Anggela, M. M., Karini, N. M. O., \& Wijaya, N. M. S. (2017). Persepsi dan motivasi wisatawan yang berkunjung ke daya tarik wisata Jembong di kabupaten $\quad$ Buleleng. Jurnal IPTA, 5(2), 76-91. https://doi.org/10.24843/IPTA.2017.v05.102.p01

Ardika, I. W. (2015). Warisan budaya perspektif masa kini. Udayana University Press. https://www.worldcat.org/title/warisan-budaya-perspektif-masakini/oclc/919105167\&referer=brief_results

Cohen, E. (1984). The sociology of tourism: approaches, issues, and findings. Annual Review of Sociology, 10(1), 373-392. https://doi.org/10.1146/annurev.so.10.080184.002105

Cooper, C., Fletcher, J., Gilbert, D., Fyall, A., \& Wanhill, S. (2005). Tourism: principles and practice. Pearson Education.

Fitriana, R., Rahmitasari, N., \& Yoseli, M. (2020). Analisis motivasi pengunjung Museum Macan Jakarta. Jurnal Ilmiah Pariwisata, 25(1).

Gaffar, V. (2011). Pengaruh strategi positioning museum terhadap kunjungan wisata edukasi di kota Bandung (survey segmen pasar generasi Y). Tourism and Hospitality Essentials (THE) Journal, 1(1), 15-32. https://doi.org/10.17509/thej.v1i1.1878

Gnanapala, W. K. A. (2015). Tourists perception and satisfaction: implications for destination management. American Journal of Marketing Research, 1(1), 7-19. http:// www.publicscienceframework.org/journal/paperInfo/ajmr?paper $\underline{\mathrm{Id}=1066}$

Inskeep, E. (1991). Tourism planning: an integrated and sustainable development approach. Van Nostrand Reinhold. https://www.worldcat.org/title/tourism-planning-an-integrated-andsustainable-development-approach/oclc/611294478

Jansen-Verbeke, M., \& Van Rekom, J. (1996). Scanning museum visitors: urban tourism marketing. Annals of Tourism Research, 23(2), 364-375. https:// doi.org/10.1016/0160-7383(95)00076-3

Muhson, A. (2006). Teknik analisis kuantitatif. In Universitas Negeri Yogyakarta.

Pristiwasa, I. W. T. K. (2017). Motivasi dan persepsi wisatawan terhadap potensi wisata di kepulauan Mentawai. Jurnal Kepariwisataan Dan Hospitalitas, 1(2), 111-117. $\quad$ https://journals.upi-yai.ac.id/index.php/IKRAITHEKONOMIKA/article/view/428

Rohman, M. M. (2014). Analisis motivasi dan perilaku pengunjung di Museum Manusia Purba Sangiran klaster Krikilan dengan metode spatial tracking study. Jurnal Sangiran, 3, 188-203.

Ruci, D. (2016). Pengaruh motivasi dan disiplin kerja terhadap kinerja pegawai puskesmas Tambang kecamatan Tambang kabupaten Kampar [Universitas Islam Negeri Sultan Syarif Kasim Riau]. http://repository.uinsuska.ac.id/id/eprint/4032

Sayangbatti, D. P., \& Baiquni, M. (2013). Motivasi dan persepsi wisatawan tentang daya tarik destinasi terhadap minat kunjungan kembali di kota wisata Batu. Jurnal Nasional Pariwisata, 5(2). https://doi.org/10.22146/jnp.6372

Sugiama, A. G. (2011). Ecotourism: pengembangan pariwisata berbasis konservasi alam. Guardaya Intimarta.

Suwantoro, G. (1997). Dasar-dasar pariwisata. Andi.

Trisnawati, N., \& Idaman, N. (2019). Motivasi pengunjung mengunjungi 
museum di kawasan kota tua Jakarta. Ikra-Ith Ekonomika, 2(1), 125-136.

Walgito, B. (2004). Pengantar psikologi umum (Andi H).

Wibowo, A. J. I. (2015). Persepsi kualitas layanan museum di Indonesia: sebuah studi observasi. Jurnal Manajemen, 15(1). https://doi.org/10.28932/jmm.v15i1.24

Wibowo, N. B. P. (2012). Pengaruh motivasi wisata, persepsi tentang daya tarik dan kualitas pelayanan terhadap lama tinggal wisatawan di provinsi DIY. Jurnal Nasional Pariwisata, 4(1). https:/ / doi.org/10.22146/jnp.6682 
This page was left intentionally blank. 
This page was left intentionally blank. 